\title{
ARE THERE ANY INDONESIAN PHILOSOPHERS? \\ DEALING WITH A COMMON QUESTION AND POSSIBLE ANSWERS
}

\author{
Al Makin \\ Sunan Kalijaga State Islamic University, Yogyakarta \\ Email: almakin3@gmail.com
}

\begin{abstract}
This article is an attempt to expose the idea of, or possibility to reclaim, Indonesian philosophy, but it is not the intention of this article to go into a detailed reading of particular works. It aims at offering a modest proposal, or an outline, sketching many possibilities of reading Indonesian works. It deals with a daunting question often posed by Indonesian students and scholars whether Indonesia can produce a philosopher or philosophical works. This article starts with addressing the question and looks for possible answers through classical Indonesian works not only from writing tradition but also material cultures, such as architectural works. It argues that Indonesian works are materials and sources worth rereading and reinterpreting through which Indonesian philosophers or philosophical works can be reclaimed, or at least unearthed. Although these works may not sound philosophical, the ways in which readers appreciate them can lead to the discovery of a unique Indonesian philosophy.
\end{abstract}

Keywords: Indonesian philosophy, reinterpretation and rereading, reclaiming Indonesian philosophers, classical manuscripts, material works, modern works.

DOI: http:/ / dx.doi.org/10.20414/ujis.v20i1.826

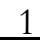




\section{Introduction}

THIS ARTICLE begins with addressing the question whether philosophical works and philosophers are found in Indonesia. The question seems to bother many Indonesians, but was posed a long ago by Indonesian leaders during the late twentieth century in the context of searching identity of the nation in the struggle for Indonesian independence. Having the question in mind, they did produce creative works which we, nowadays as readers, should appreciate to find an epistemological foundation in an attempt to designate their pieces as philosophical works. This article briefly presents a modest outline of possibility of appreciating these works by briefly mentioning the works of Soekarno, Tan Malaka, and Tjokroaminoto, which we could reread and reinterpreted with a new perspective. This article intends to show that indeed these works contain some elements of philosophy. Indeed, the definition of philosophy should be broadened in reading sources so much so that philosophical foundation can be discovered. This article then proceeds to briefly mention the works written during the New Order which also offer different philosophical formulation. As this article offers a proposal, or outline, of possibility in philosophizing Indonesian works with sketching general ideas, this article does not intend to choose particular works and explain them in a detailed way, but it proposes a sketch, or outline, of four kinds of works which are worth readings and reinterpreting: ancient Hindu-Buddhist works in the forms of writing, oral, and material cultures, Islamic literature which still continued the norms and ethic of the past, and the works of Indonesian leaders during the era of awakening nationalism.

By proposing such an outline this article tries to offer a possible epistemological foundation of Indonesian philosophy, which can be further developed through a meticulous study, by appreciating basic elements of philosophy, and philosophizing them. It begin with addressing the question and discussing a proposal which can lead us to find possible answers by randomly mentioning some works along the history of Indonesia. This article does not specifically focus on particular 
work, but offers a sketch, or an outline, of possible answer in addressing the abovementioned question.

\section{The question}

This article seeks to address a daunting question 'are there any Indonesian philosophers?' Neither the question nor the answer is simple. What is clear is that the possible answers depend on the way in which the word 'philosophy' itself is defined: what philosophy is and what subjects are included in the field. Cambridge English dictionary gives the definition as follows: "the use of reason in understanding such things as the nature of reality and existence, the use and limits of knowledge and the principles that govern and influence moral judgment."1 This definition encompasses broad areas of knowledge which tries to describe reality and existence from time to time along human history. However, as the field is immensely broad, the Cambridge dictionary of philosophy does not have an entry of the word philosophy itself. However, the beginning of the work mentions the vast areas of philosophy's achievement: "Philosophy has always done extraordinary things with ordinary terms-'believe' and 'know', 'cause' and 'explain,' 'space' and 'time,' 'justice' and 'goodness,' 'language' and meaning', 'truth' and 'beauty', 'art', 'religion,' 'science,' 'mind', 'perception', 'reason', and countless others." 2 Yes indeed philosophy cannot be easily defined in words or paragraphs. Audi writes"...no short definition is adequate. It will not do to define 'philosophy' in the etymological way many have, as 'the love of wisdom': granting that it is natural for philosophers to love wisdom and for many lovers of wisdom to be inspired to pursue philosophy, a lover of wisdom can be quite unphilosophical, and even a good philosopher can be wise in at most a few domains of inquiry." 3

1 Paul Procter, ed., Cambridge International Dictionary of English. (Cambridge; New York: Cambridge University Press, 1995), 1058.

${ }^{2}$ Robert Audi, The Cambridge Dictionary of Philosophy (Cambridge; New York: Cambridge University Press, 1999), xxvii.

IIbid., xxix. 
Given the broad definition of philosophy, or the word itself cannot be easily defined, the field of inquiry is open. And in reading the works produced along the history of the archipelago of Nusantara philosophy can be discovered. In addition, if philosophy is defined as a system of thinking by which we question and answer many curiosities and observation with regard to universe, man, or God, certainly every culture has a unique way of producing philosophy, born from the mind of unique 'philosophers.' But if we set a rigid criteria in defining philosophy only referring to a certain tradition of philosophical thinking, such as Greek, Rome, Arab, Chinese or other kinds of philosophy, the answer of our question is more certain, although it is relatively various. In fact the history of philosophy is never finished. Western philosophy has its own history, starting from Greek, Roman, classical, medieval, and modern philosophy. In the field, there are many areas, from speculative, ${ }^{4}$ political, ${ }^{5}$ and philosophy of science. In the Cambridge dictionary we find many other specific branches of philosophy, from education, biology, mathematics, anthropology, economics, history, religion, etc. ${ }^{7}$ In terms of regions, philosophy can vary too, such as Arabian, Chinese, Indian, American, and so forth. Given this, Indonesia should has its own history of philosophy and the way people put their mind using their wisdom and values, although the word philosophy may not explicitly be mentioned in the works by Indonesians. But the current readers can 'philosophize' the materials and sources taken from the works penned by Indonesians.

The world in nowadays globalization is well connected; surprisingly so was in the past. If in the past people might fail to see the connection among many people in different regions, such as ancient China and Rome, nowadays scholars will do so with finding evidences to construct the connection between one region to another. Is there any connection between Indonesia

${ }^{4}$ Saxe Commins and Robert N Linscott, eds., Man and Spirit: The Speculative Philosophers (New York: Random House, 1947).

5Ibid.

6 Ibid.

${ }^{7}$ Audi, The Cambridge, 667-706. 
and Greek? So far we have no translation of Republic by Plato in Nusantara prior to Western colonialization. But a rather indirect relation between Greek and Nusantara in much later time can be explained. What is clear is that the relation of East Indies (Indonesia during the Dutch colonial time) and European culture during the end of Dutch colonialism, in which Ethical policy was implemented, enabled few fortunate Indonesians to pursue Western education, through which the influence of Greek philosophy and modern Western thoughts penetrated their way of thinking. ${ }^{8}$ In this vein, the influences of European philosophy on the leaders of the movement of Indonesian independence cannot be ignored. It is not hard to guess that through European colonialization, some elements of Greece tradition indirectly came to Indonesia. Obviously, most Indonesian leaders of the movement for the nation's independence with the spirit of nationalism cited the works of major European thinkers, such as Karl Marx, Hegel, and other Western literary works such as novels.

In fact, Indonesian nationalist leaders such as Tan Malaka, Sukarno, ${ }^{10}$ Tjokroaminoto ${ }^{11}$ often presented European thought in their works, particularly related to the issues of socialism, nationalism, communism in their effort to support and proliferate the ideas of the struggle for the independence of the nation and to promote reformation of culture and education in the East Indies. During the time of revolution Indonesian leaders were indeed creative in blending Western thoughts, Islamic teachings, and local contexts with the aim to introduce new ideas and to educate their fellow Indonesians. Their works, however, were often seen as journalistic works in nature, not philosophical works, if we rigidly perceive 'philosophy' as a

8Parakitri Tahi Simbolon, Menjadi Indonesia (Jakarta: Kompas, 1995).

'Tan Malaka, Madilog, Materialisme Dialektika Logika (Jakarta: LPPM Tan Malaka, 2008).

10 Soekarno, Dibawah Bendera Revolusi. (Djakarta: Panitya Penerbit Dibawah Bendera Revolusi, 1963); Soekarno, "Nasionalisme, Islamisme, dan Marxisme," in Dibawah Bendera Revolusi. (Jakarta: Yayasan Bung Karno, 2005), 1-22.

${ }^{11} \mathrm{Um}$ ar Said, Tjokroaminoto, Islam dan sosialisme (tertulis di Mataram dalam bulan November 1924). (Djakarta: Bulan-Bintang, 1954). 
system of thinking in a particular way. However, if we broaden our understanding of philosophy as mentioned above, certainly their works offer value, norm, wisdom, knowledge, reasoning, and other process of philosophical reflections. What is more, we as readers have a vital duty to appreciate and read their works philosophically and find philosophical foundation in them. As recorded in the history of the East Indies, after the adoption of Ethical Policy by the Dutch colonial government, the creative way of mixing of European philosophy and Indonesian ingredients, with the effort of searching identity, was common. All in all, in the end of nineteenth and early twentieth centuries, Indonesian thought was under the influence of Western thought and Eastern traditions, such as Gandhi, Kemal Ataturk, Pan Islamism, etc. Perhaps the earliest and most complete document during this period we can read is Kartini's letters, ${ }^{12}$ which offers a critical insight into Javanese tradition and dream of more progressive Western tradition. If we consider a broad definition of philosophy, the critical insight is a vital part of philosophical inquiry. In addition, during the heyday of nationalist and patriotic sentiment, this trend, by which many promoted the adoption of European school of thoughts, became apparent. The unique philosophical attempt lies in the effort of marrying the European way of thinking and Indonesian context leading to produce a unique way of reflection. Early leaders of nationalist movement, such as Muhammad Yamin, also did so in this direction. In his effort to explain the importance of nationalist awareness for the people of the archipelago, not only did Muhammad Yamin return to the definition of nationalism as understood in European history, but he also recalled the history of Indonesia before colonial period. In doing so, he returned to

${ }^{12}$ Kartini, Aku mau .... feminisme dan nasionalisme: surat-surat Kartini kepada Stella Zeehandelaar 1899-1903, trans. Vissia Ita. Yulianto (Jakarta; Yogyakarta: Buku Kompas; [Program Pasca Sarjana Ilmu Religi dan Budaya (IRB), Universitas Sanata Dharma Press] IRB Press, 2004); Kartini, Letters from Kartini: An Indonesian Feminist, $1900-1904$ (Clayton, Vic.; Melbourne, Vic.: Monash Asia Institute, Monash University; Hyland House, 1992); Kartini, Surat-surat Kartini: renungan tentang dan untuk bangsanya, trans. Sulastin, Sutrisno (Jakarta: Djambatan, 1979). 
the figure of Gajah Mada, the prime minister of Majapahit, considered as a hero who contributed to the idea of the unity of the archipelago. During the time of revolution, many Western schools of thought, such as socialism, Marxism, idealism, communism, to mention but few, were commonly referred to by Indonesian leaders. Yamin is not exceptional. In his foundation of thinking Yamin used Friedrich Hegel's idealism and dialectics; ${ }^{13}$ particularly in putting the ideas in the reality of Indonesia, Yamin recalled the greatness of the past, such as Sriwijaya and Majapahit. ${ }^{14}$

The question of whether there are any Indonesian philosophers is scholarly and yet patriotic statement. This curiosity, along with the effort of searching the identity of the people of the archipelago, bothered the leaders of nationalist movement in the early twentieth century. Interestingly, the patriotic question of national identity never faded away after Indonesia achieved its independence and later built the government. The spirit of patriotism remained vital in building the new nation. Sukarno, the first president of Indonesia, stressed this idea rhetorically in many occasions. This spirit continued in the later period after Sukarno's fall. Many projects during the New Order also gave this impression that the search for identity - in the forms of questions such as who Indonesians are and how Indonesia should be defined-continued. Nugroho Notosusanto was among the ideologues who penned the history of Indonesia by means of 'indoctrination', in accordance with the interpretation of history by the New Order. ${ }^{15}$ Notosusanto's

${ }^{13}$ Herbert Feith et al., Indonesian Political Thinking, 1945-1965, (Ithaca N.Y.: Cornell University Press, 1970).

${ }^{14}$ Note that many pre-colonial works were studied by Dutch scholars, e.g. Jan Laurens Andries. Brandes, ed., Pararaton, Ken Arok, of Het Boek Der Koningen van Tumapel En van Majapahit Uitgegeven En Toegelicht Door Dr J. Brandes. Javan. and Dutch. (*. 314. 1896, 1896).

${ }^{15}$ Nugroho Notosusanto et al., Sejarah nasional Indonesia: untuk. SMA (Jakarta: Departemen Pendidikan dan Kebudayaan, 1981); Nugroho Notosusanto, Sejarah nasional Indonesia untuk SMP. (Jakarta: Departemen Pendidikan dan Kebudayaan: Balai Pustaka, 1985); Nugroho Notosusanto, Tentara Peta pada jaman pendudukan jepang di Indonesia (Jakarata: Gramedia, 
philosophical history promotes a political propaganda under the hegemony of the New Order to highlight the new version of national identity and to lead the younger generation to blame the past, i.e. Sukarno's failure, and to welcome the new political system of Soeharto. The project undertaken by the New Order included reinterpretation of Indonesian independence, the foundation of the state, Indonesian heroes, development of the young nation, and the direction to which the nation under the New Order should move. What the word 'direction' in this regard means is to redefine the meaning of the nation in accordance with the New Order's political hegemonic interests and strategy. What is the most importance part of this forming national identity is the effort to deny Sukarno's legacy, and finding new legitimacy to rule the country. In its rhetoric, the New Order did not intend to return to the golden time of revolution's dream, because the moment belonged to Sukarno, but the New Order stressed the time when Sukarno fell from power, that is the 1965 national tragedy. For many Indonesians who experienced the reform period, that is the fall of Soeharto in 1998, the 1965 means a shame of the nation, in which many innocent Indonesian citizens were massacred. ${ }^{16}$ However, during the heyday of the New Order, the 1965 was a moment in defining the new national identity by promoting a new 'enemy.' During Sukarno's period, the enemy was the Dutch colonial government which deprived the nation's wealth and exploited the people. During the end of Sukarno's era, the West, particularly represented by the US, was pointed as the new enemy; using Marxist language, Sukarno pointed the West as a capitalist power which cunningly exploited the developing nations' wealth. Sukarno thus established his own role as the leader of a new block, a neither communist nor capitalist power. Soeharto, however, did not continue Sukarno's rhetoric but found that 'communism' can be blamed for the 1965 upheaval.

1979); Nugroho Notosusanto, Tercapainya konsensus nasional, 1966-1969 (Jakarta]: Balai Pustaka, 1985).

${ }^{16}$ John Roosa, Pretext for Mass Murder the September 30th Movement and Subarto's Coup D'etat in Indonesia (Madison, Wis.: University of Wisconsin Press, 2006). 
All political rhetoric during the New Order, promoted in education, thinking, and state policy, was anti-communist propaganda. Indonesian philosophy, if we attempt to reclaim it, cannot be split from these dynamic contexts.

Furthermore, the question of the existence of Indonesian philosophers were often posed and motivated by a desperate effort to seek the foundation for Indonesian scholarship. This endeavor may be based on an amazement of the way in which global scholarship has lately moved fast and Indonesian scholarship seems lag behind. In Indonesian understanding, the world of scholarship, including philosophy, is based upon two major traditions, Greek and Eastern wisdoms. Greek philosophy is often combined with theology of Semitic tradition, from Judaism, Christianity to Islam. Eastern philosophy, such as Indian, Japanese, and Chinese traditions, are also known among Indonesians but not studied well. On the other hand, the majority of Indonesians who embraced Sunni Islam paid attention to religious and theological foundation of classical Islamic philosophy. But, early Islamic philosophers under the liberal spirit of Mu'tazilite school of thoughts, such as al-Kindi, al-Jạhiz, Ibn Sinā, Ibn Miskawayh and Ibn Rushd, are not studied well. Indonesian students read the works of Muslim philosophers at the IAIN/STAIN/or UIN (State Islamic Institute/University) through Western scholarship. ${ }^{17}$ Students of traditional boarding school (pesantren) and madrasab do not study the works of these Muslim philosophers. But the works of alGazā $\Gamma^{18}$ who combined Islamic orthodoxy and the movement of

${ }_{17} \mathrm{Al}$ Makin, IAIN and McGIll Cooperation, 10 Years: Past and Future (Yogyakarta: Local Project Implementing Unit, 2003); Jabali, Fuad and Jamhari, The Modernization of Islam in Indonesia: An Impact Study on the Cooperation between the IAIN and MoGill University (Jakarta and Montreal: Indonesia Canada Islamic Higher Education Project, 2003).

${ }^{18 M a s s i m o ~ C a m p a n i n i, ~ " A l-G h a z z a l i, " ~ i n ~ H i s t o r y ~ o f ~ P h i l o s o p h y, ~ e d . ~ S e y y e d ~}$ Hossein Nasr and Oliver Leaman, vol. 1 (London: Routledge, 1996), 258274; Abū Hāmid Mụ̣ammad ibn Muhammad al-Gazāil, Deliverance from Error (Al-Munqidh min al-D aläl), trans. Richard J. Mccarthy (Beirut: American University of Beirut, 1980); Abū Hamid Muhammad ibn Muhammad alGazāil, Freedom and Fulfillment: An Annotated Translation of al-Gazatis al- 
anti-philosophy have a deep impact upon Indonesian philosophical reflections. Ibyya 'Ulüm al-Dīn, ${ }^{19}$ which promotes Sufism and orthodoxy, is popular in traditional Indonesian Islamic education. In reality, theology indeed prevails over philosophy in Indonesian Muslim tradition. Practical Sufism has a special place in Indonesian religiosity and reflection. ${ }^{20}$ But lately, due to the fever of Sharia after the reform period, Sufism as a philosophical thinking which promotes interreligious tolerance seems abandoned. Rather, people stress the formality of Shari'a in the form of local regulations. Indeed, formal symbols of Sharia in the spirit of local regulations (Perda) become a major trend in the current political identity and commodities in political campaigns. ${ }^{21}$ In this situation conservatism and radicalism is on the rise. ${ }^{22}$ Philosophy is forgotten.

But when the question of Indonesian identity, such as where to go after democratization in the aftermath of Soeharto's fall, was posed, many return to the basic question, that is what

Mungidh min al-Dalal and Other Relevant Works of al-Gazali, trans. Richard Joseph McCarthy (Boston: Twayne Publishers, 1980).

${ }^{19} \mathrm{Abu}$ Hămid Muhammad ibn Muhammad al-Gazāil, Revival of religion's sciences/Ibya' 'Ulüm al-din, ed. Muhammad Mahdī Sharīf (Beirut: Dār al-Kutub al-'Ilmiyyah, 2011).

20Julia Day How ell, "Modernity and Islamic Spirituality in Indonesia's New Sufi Networks," in Sufism and The "modern" in Islam, ed. Martin van Bruinessen and Julia Day Howell (London; New York; New York: I.B. Tauris; In the U.S.A. and Canada distributed by St. Martin's Press, 2007), 217-240.

${ }^{21}$ Muhammad Ansor, "Being Woman in the Land of Shari'a: Politics of the Female Body, Piety, and Resistance in Langsa, Aceh," Al-Jami'ab: Journal of Islamic Studies 52, no. 1 (June 2014): 59-83; "Permasalahan Implementasi Perda Syariah Dalam Otonomi Daerah: View Article," Journal al-Manahij 7 , no. 2 (2013).

${ }^{22} \mathrm{Al}$ Makin, "Benedict XVI and Islam: Indonesian Public Reactions to the Regensburg Address," Islam and Christian-Muslim Relations 20, no. 4 (2009): 409-421; Al Makin, Challenging Islamic Orbtodoxy: The Accoounts of Lia Eden and Other Prophets in Indonesia (Dordrecht, Holland; Cinnaminson [N.J.], U.S.A.: Springer, 2016); Al Makin, "Revisiting Indonesian Public Reactions against Danish Cartoons Depicting Prophet Muhammad," Indonesian Journal of Islam and Muslim Societies 5, no. 2 (2015): 195-229. 
foundation of thinking Indonesians should build in response to the current globalization. Whether they should return to religious piety or rational thinking (both of which are imported and are not true own tradition) remains unclear. Note that six religions-Islam, Catholicism, Protestantism, Hinduism, Buddhism, and Confucianism-officially acknowledged by the government are products of foreign cultures (Middle Eastern, European, Indian, and Chinese). ${ }^{23}$ In fact indigenous religions are marginalized and were often faced with the government's discriminative attitude against them. They are considered as mere cultures, not religions. Thus returning to the six religious traditions means admitting indirectly that Indonesians are cosmopolitan and at the same time admitting that Indonesian traditions consists of different parts of foreign elements. The six abovementioned religions are nothing but foreign products but adopted and adapted to Indonesian contexts. On the other hand, in rational thinking, Indonesians have no clear background in producing works which have influence on later generations. The answer to the question of whether rational thinking or religious piety should be taken in Indonesian epistemology is not simple. Yet, to find Indonesian own tradition or to admit that Indonesians should adopt Western thought is not easy either. To embrace rational thinking cannot avoid Western philosophy based on the spirit of European enlightenment which so far leads the current globalizing world. Still, to combine religious traditions and Western philosophy is as complicated as the question itself. As Islam is the religion of the majority of Indonesians, Islamic philosophy based on faith and theological discussion becomes an issue which always occupies Indonesian scholarship. However, the question is not entirely new. Early leaders of nationalist movement, as mentioned above, were aware of this issue.

${ }^{23} \mathrm{Al}$ Makin, Challenging Islamic Orbtodoxy: The Accoounts of Lia Eden and Other Prophets in Indonesia (2016). 
Tjokroaminoto, Tan Malaka, ${ }^{24}$ Sukarno and later generations were puzzled with the question: local and foreign tradition or Islamic and secular tradition. But in fact Muhammad Yamin was in the right direction when trying to combine Western thought and the history of the archipelago. In other words, Yamin sought to find the past in order to create the identity of the future. His choice fell into Majapahit's glorious myth: Hayam Wuruk and Gajah Mada, believed to have united the archipelago, a unity which later becomes an archetype of modern Indonesia. In Sumatera many also returned to Sriwijaya, the old kingdom which predated Majapahit, uniting the archipelago by building sea transportation. Given this, returning to the nation's history by reading and reinterpreting classical literature from which new tradition can be invented is a right path which should lead our philosophical inquiry. The answer to our question whether Indonesia has its own philosopher is yes, it does, but we should do as what early Indonesian leaders have done so, that is by appreciating the previous works but with the spirit of reinterpretation.

Now the question over the existence of Indonesian philosophers is not a modest curiosity. It involves search for identity and foundation not only in scholarly works but also a broader national scope which have been addressed since the revolution of Indonesian independence.

\section{A Proposal}

To answer the question about the existence of Indonesian philosophers is a long run project. This paper does not intend to give a final and complete answer. Nor does this paper present an example of the project. However, this paper will propose a sketch, or outline, of what can be done to define Indonesian philosophy and to define Indonesian philosophers. Once again, to argue that Indonesia ever produces its own philosophers does not mean that we will present self-proclaiming local philosophers with their philosophical compendiums. What we

${ }^{24}$ Tan Malaka, Naar de Republiek Indonesia, 2013; Tan Malaka's Naar de Republiek Indonesia: A Translation and Commentary: Geoffrey C. Gunn. (Nagasaki, Japan: Hakkojo, 1996). 
can pursue is that the current generation has a duty to read manuscripts and works by writers in the history of the archipelago whose works are not explicitly all about philosophy or any system of thinking. Their works are written in various forms of poems, diaries, doctrinal religious teachings, or merely unclear records carved on the stones of temples. The term philosophy is not mentioned explicitly. But our task is to rediscover some elements, or foundation, of philosophy in them and to systematize them. In other words, it is possible to 'philosophize' these works and appreciate what they contain and treat them as philosophical works. In doing so, we should reread them based on philosophical principles. To treat these works as precious as philosophers' pieces with which we are familiar is not an easy task, which is a long enduring project. As we know in hermeneutical philosophy the task of interpretation is never once completed, but reinterpretation is demanded in different time and space. Thus, what Indonesians have written should be reinterpreted based on new demands and new way of reading, thus giving new meaning based on new contexts. Of course we will be disappointed, as we hardly find the works by Indonesians as philosophical and systematic as those of Aristotle or Plato, or those of any classical Muslim philosophers such as al-Fārābi, Ibn Sinā, or Ibn Rushd. Nor are their works similar in any level to those of the known modern philosophers. But as a basic rule, thinkers or philosophers earned great names due to their works which were appreciated in the scholarly world afterwards. They did write great books, so much so that their disciples venerated them. But they earned reputation, mainly because later generation appreciated their works and continued their legacy. Let us take al-Shäfici the founder of Shafi'i school in the field of Islamic jurisprudence with millions adherents in the Muslim world. He remains indeed influential and is respected until today for his great mastery in fiqh (Islamic law). But in fact his works such as al-Umm or al-Risalah are not sufficient in defining his greatness. ${ }^{25}$ Great thinkers become great because they produced

${ }_{25}$ Norman Calder, Studies in Early Muslim Jurisprudence (Oxford: Clarendon Press, 1993); Kecia Ali, Imam Shafii: Scholar and Saint (Oxford, England: Oneworld, 2011). 
students who venerated them after the teachers' death. The greatness of thinkers came into reality after their death with their works having influenced the world afterwards. Plato is great not only because of his Republic ${ }^{26}$ which is influential on many cultures and has been translated into Latin, Syriac, Arabic, English and other hundred world languages. ${ }^{27}$ But his greatness also lies in the act of appreciation and reinterpretation by later philosophers in various generations and cultures which keep the tradition of the Republic alive. Similar cases are with other Western thinkers whom later generations venerated. ${ }^{28}$

The problem in Indonesia, however, is that we do have thinkers or writers, who penned numerous works, but, to put simply, we do not have 'good' readers or those who appreciate their works sufficiently. We have no school of Majapahti, Demak, Mataram, Yogyakarta, Solo, Ciputat, or Sapen, or other literary circles that reinterpret, or at least appreciate, their works. To argue in this vein, Indonesia indeed has thinkers with their works influential on later generations, such as Negara Kertagama ${ }^{29}$ whose fame lies in the words Bhinneka Tungga Ika, adopted as the Indonesian symbol of diversity and unity. However, Kertagama needs new readers who are committed to see the work in a different way and in a new light and to reinterpret what it contains. To read the work as it was written in the old Majapahit context does not help us in defining and discovering 'Indonesian philosophy,' as proposed in this article. Kertagama, like the Republic, will live on in the hands of new readers who are prepared to assign new meanings. If we read the Republic, or Arabic books such as Iby a by al-Gazāil, and appreciate them as the works of philosophy, the issue is why we do not treat Kertagama well as we did with the Iby $\overline{\text {. }}$

${ }_{26}$ Plato, The Republic, ed. G. R. F Ferrari, trans. Tom Griffith (Cambridge, New York: Cambridge University Press, 2000).

${ }^{27} \mathrm{Al}$ Makin, Keragaman dan Perbedaan, Budaya dan Agama dalam Lintas Sejarah Manusia (Yogyakarta: Suka Press, 2016).

${ }^{28}$ Bertrand Russell, History of Western Pbilosophy and Its Connection with Political and Social Circumstances from the Earliest Times to the Present Day (London: Routledge, 1999).

${ }^{29}$ Slamet Muljana, Tafsir Sejarah Negara Kretagama (Yogyakarta: LKiS, 2006). 


\section{Unearthing four possible sources}

Indonesian philosophy, if we intend not only to reclaim the 'term' but also to develop it with scholarly discussion of philosophy, needs to find roots in the Indonesian soil from which knowledge can grow and be cultivated in fostering our endeavor of reinterpretation. What we can do is to unearth 'treasures' of the past, by excavating, discovering, and appreciating them. By doing so, this article offers an outline of four possible sources of knowledge (epistemology) which can be further developed by our generation: 1) Hindu-Buddhist tradition; 2) local wisdom; 3) Islamic literature; and 4) modern foundation of thinking. Let us briefly explain one by one:

(1) Reinterpreting the previous Hindu Buddhist traditions is rereading not only written works such as books but it also covers material cultures, such as temples or ancient architectural works. If we are fortunate to find an old manuscript, then our task is also to appreciate the source. Note that material cultures still beg our new way of reading. We are fortunate that old writings such as Syang Hyang Kamahayanikan is still at our disposal. But generally speaking, we inherit too few writings from this old tradition. However, material sources in the form of temples found across Yogyakarta, East Java, Central Java, Sumatera and Kalimantan are at our disposal which can be read with new interpretation. Keep in mind that Hindu Buddhist temples contain unlimited wisdoms and priceless knowledge about the way our ancestors brought and put Indian traditions into the context of Nusantara. In short, the idea and reason behind adopting and adapting foreign wisdom put in the new context of Nusantara still challenge our new way of reading.

(2) We should reinterpret local traditions and wisdoms still transmitted orally until today and which become living traditions still retained in many local religious practices. Like material cultures preserved in the architectural works, this source also needs rereading. Ironically this old wisdom has no place in the current Indonesian discussion and the government's policy. This is so because the government's attitude fails to appreciate local wisdoms. Note that Indonesians embrace foreign religions and wisdoms as mentioned above, but, on the other hand, local 
wisdoms and oral traditions still survive. But oftentimes we do not realize the latter's existence among increasingly dominating 'global' religious traditions and cultures, i.e. Semitic tradition which dominates the country's faith. Ironically, the government retains the irrelevant blasphemy law 1965 by which to prosecute those who claimed 'local religions' and traditions. Many anthropologists and ethnologists, on the other hand, have discovered various unique local religious traditions in Indonesia, but they treated the traditions as mere 'local traditions', not as a system of thinking, not appreciated as 'philosophical works'. In this regard, the vital task put on our shoulder is to reinterpret these local wisdoms and treat them as an indigenous 'philosophy', that is to consider them as a system of thinking which can lead us to a new perspective.

(3) Islamic literature encompasses broad areas of written literature in the early years of Indonesian Islam, which has shaped a unique Islamic identity, which is currently ignored amidst the current discussion of the resurgence of Islamism and radicalism in Indonesia. Of course, the history of Indonesian religiosity witnesses that Sumatera is a home to Hamzah Fansuri, ${ }^{30}$ Nuruddin al-Singkili, and other Sufi writers who penned their wisdom by mixing local culture, Persian, Indian, and Arab tradition to express their religiosity. Keep in mind that Sulawesi is also a place where syncretistic tradition remains alive until today. New traditions are often born in this island. Likewise, Nusa Tenggara also gives birth to a unique tradition of mingling Hinduism, Islam and local traditions. ${ }^{31}$ Of course, the island of Java becomes an important center of religious traditions which has produced various syncretistic practices of

30Sangidu, "Allah Maujud Terlalu Baqi Karya Syeikh Hamzah Fansuri: Analisis Semiotik," Diksi 11, no. 1 (2004): 1-19; Sangidu, "Ikan Tunggal Bernama Fadhil Karya Syeikh Hamzah Fansuri: Analisis Semiotik," Humaniora 15, no. 2 (2003): 191-199; Syarifuddin, "Memperdebat Wujudiyah Syeikh Hamzah Fansuri (Kajian Hermeneutik Atas Karya Sastra Hamzah Fansuri)," Religia 13, no. 2 (2010): 139-156; Sangidu, "'Sidang Fakir Empunya Kata' Karya Syaikh Hamzah Fansuri Kajian Filologis dan Analisis Semiotik," Humaniora 14, no. 3 (2002): 306-317.

${ }^{31} \mathrm{Al}$ Makin, Challenging Islamic Orbtodoxy: The Accoounts of Lia Eden and Other Prophets in Indonesia (2016). 
many faiths. However, for the sake of our purpose to reclaim 'indigenous philosophy', many figures and leaders who revealed wisdoms should be seen as 'philosophers' not merely as local religious leaders. In this vein, we readers should reinterpret their revelations. Many historians, anthropologists, and sociologists, however, were tempted to treat them as an ethnological data rather than as a system of philosophical reflection which deserves a special attention. ${ }^{32}$

(4) Modern Indonesian thinkers, abundantly found from the time of the Dutch colonial period to the time of reformation, can also become a subject of philosophical source, that is epistemology. As mentioned above, princess Kartini's letters can serve as a foundation which remains influential in Indonesian literary tradition in the themes of feminism and the movement of nationalist awareness. Furthermore, numerous works by later leaders, such as Tan Malaka, Soekarno, Yamin, Tjokroaminoto, and others, who injected the spirit of nationalism to Indonesians, as mentioned earlier in this article, can also serve as another epistemological foundation. These works contain philosophical reflection which should be restructured and criticized with the spirit of appreciation as an attempt to 'philosophize' their works and to find important concepts of humanity, theology, politics, and epistemology. By reading these works with a critical attitude, at least the foundation of epistemology of Indonesian philosophy can be unearthed. In reading these works we can perhaps propose several categorizations and phases (it depends on how we see them and the categorization should be neither 'doctrinal' nor 'dogmatic', like what political propaganda performed by the Old and New Order), such as: pre Independence, after independence, during the New Order, and after the collapse of Soeharto. Other

${ }^{32}$ Clifford Geertz, Abangan, Santri, Priyayi: dalam Masyarakat Jawa, ed. Bur Rasuanto, trans. Aswab Mahasin (Jakarta: Pustaka Jaya, 1983); Clifford Geertz, The Religion of Java (Glencoe, Ill.: The Free Press, 1960); Clifford Geertz, Islam Observed: Religions Development Marocco and Indonesia. (New Haven [etc.]: Yale University Press, 1968); Clifford Geertz, The Interpretation of Cultures: Selected Essays (New York: Basic Books, 1973). 
categories can also be used, such as based on theme, political thinking, religious ideology, societal analysis, and so on.

\section{Recalling ancient wisdom}

But before proceeding to the latest modern work, a foundation of the past should be discovered. Perhaps the oldest writing in the archipelago which remains at our disposal is the Sang Hyang Kamahayanikan which contains Buddhist Tantric philosophy showing how to achieve enlightenment. ${ }^{33}$ The work also reveals some examples of attitude and practices of Tatagatha. The statues of Tatagatha can also be found in many Buddhist temples in Central Java and Yogyakarta the main verb is missing. Thus comparison can be made between Tatagatha in Kahamayanikan and the statues of the temples. Borobudur, for instance, shows various attitudes and positions of Tatagatha which can be compared to the description in the book. ${ }^{34}$ All in all, the Kamahayanikan needs reinterpretation not only from the perspective of Buddhist religiosity but also as the way ancient Indonesians put their thought in combining Indian tradition and local wisdoms. Iconography which serves as the foundation of building of the Borobudur remains vital in our endeavor to unearth ancient epistemology which influenced later culture and religious traditions. Borobudur itself as material culture needs rereading, such as how to achieve enlightenment in the version

33 I. Gusti Bagus Sugriwa, Kitab Sutii "Sanghyang Kamabayanikan" (Denpasar: Pustaka Balimas, 1956); Land- en Volkenkunde (LEYDEN) Koninklijk Instituut voor Taal- and Kamahayānikan, Sang Hyang Kamahayanikan. (Sang Hyang Kamabâyanan Mantranaya.) [Treatises on the Mystical and Magical Teachings of the Mantra-Yana School of Northern Buddhism, in a Series of Sanskrit Stanzas with Javanese Exposition.] Oud-Javaansche Tekst Met Inleid (s' Gravenhage, 1910); Panitya Penyusun Penterjemahan and Sanghyang Kamahayanikan, Kitab Suci Sanghyang Kamahayanikan: Naskah-TerjemahanPenjelasannya (Tahun: Proyek Pengadaan Kitab Suci Buddha, 1980); Kazuko Ishii, "Borobudur, the Tattvasamgraha and the Sang Hyang Kamahayanikan," in The Art and Culture of South-East Asia, ed. Lokesh Chandra (New Delhi: International Academy of Indian Culture and Aditya Prakashan, 1991), 151-164.

${ }^{34}$ John N Miksic, Borobudur: Golden Tales of the Buddhas (Hongkong: Periplus, 1991); Ishii, "Borobudur, the Tattvasamgraha and the Sang Hyang Kamahayanikan." 
of old Javanese culture. The philosophy of three worlds, or three phases of enlightenment: kamadhatu, rupadhatu, and arupadhatu (in Hinduism we find bhurloka, bbuwarloka, dan swargaloka)-whose meaningful symbolism was later retained in Islamic literature in the forms of shari'ah, haqiqah, and ma'rifab-should attract our attention. These phases symbolize the steps taken in achieving enlightenment in Buddhist Borobudur; the three worlds are also described in Hindu Prambanan, and in mosques of Demak, Yogyakarta, and other shrines. To explain them briefly, the world kamadathu basically means underground world which contains examples of sinful deeds which should be avoided. The second world of rupadhatu contains laws and rules in the world of human kind which more or less is comparable to sharia in Islam. Sharia is a central theme in nowadays Indonesia, as the fever of Sharia can be felt in many local regulations which can threaten the integration of the country and nation. The third world Arupadhatu sounds similar to, and indeed has becomes inspiration for, the sufi path of Islamic tradition. Arupadhatu is the world where material and worldly affairs have no values, the immaterial world of ascetism and sufism. The stage is the highest enlightenment described as haqiqah (the highest truth) or the state of ma'rifah (Gnosticism), an achievement of Sufi masters in Islamic literature explained in various oral and written traditions in Nusantara.

Hindu tradition can also serve as another foundation of indigenous epistemology. Hindu tradition leaves us with some architectural achievements visible in Central Java, Yogyakarta, and East Java. Sumatera and Kalimantan also give us this evidence, as various temples can also be found in these islands. These architectural achievements represent the worldview of Hinduism relating to the system of beliefs in Gods, Goddesses, saints, and the way in which society in the archipelago was structured in terms of political, societal, and religious hierarchy. Take for example the immense temples of sewu (thousand) in the complex of Prambanan in the border of Yogyakarta and Klaten. ${ }^{35}$ The Prambanan has the oldest relief telling the ancient

${ }^{35}$ Timbul Haryono, "Neighbouring Temples," ed. Veronique Degroot (Yogyakarta: Tamanwisata candi Borobudur, Prambanan \& Ratu Boko, 
story of Ramayana, the old Indian epic which has been staged in various forms of shows and theatres of many generations in Indonesia. The work of Ramayana, and also Mahabarata, has become an inspiration not only for Hindu and Buddhist believers, but they also remain influential in the later Islamic literature and religiosity. The story is as old as the history of India in telling the blurred difference and border of good and evil, treacherous and heroic, and loyal and disloyal. The work teaches us about the story of brothers and cousins who were involved in war for power, wealth, and love which have been reinterpreted in various forms and stages in arts, religions, and politics. Norms, ethics, philosophies, and other fields inspired later narrations in new Islamic tradition in the archipelago. The war has indeed inspired innumerable Indonesian literary works from one generation to another. One of the famous examples of the lesson learned from the war event is the way in which conversation between two heroic figures: Krisna and Arjuna. ${ }^{36}$ When Krisna served as the driver of Arjuna's chariot, the master of archery, both were involved in a long conversation about human duty, fate, and destiny (dharma and karma). It is believed that Krisna is the reincarnation of God who taught Arjuna about the philosophy of life in war. The war is not only about annihilating the enemies whom Arjuna detested, but about the war inside human mind in the forms of lush, desire, and performing duty.

Other old works in the Hindu and Buddhist traditions, whose practices mostly did not survive, need rereading using new perspectives based on current demands in the globalizing world. Both material and literary works are worth reinterpreting which should produce a new and fresh perspective in seeing the history of Indonesia. From this reading, new epistemological

2013); John N Miksic and Slamet Pinardi, Kraton Ratu Boko: a Javanese site of enigmatic beanty (Yogyakarta: PT (Persero) Tamanwisata candi Borobudur, Prambanan \& Ratu Boko, 2015).

36Bhagavad-Gitâ; or the Secred Lay: A Colloquy between Krisna and Arjuna on Divine Matter, an Episode from the Mababharata; a New Edition of the Sanskrit Text with a Vocabulary, by J. Cockburn Thomson, and Translated by the Same, with Copious Notes and I (Hertford: Austin, 1855). 
foundation can be built; indeed the past can neither be forgotten nor ignored. In short, the archeological attempt of Indonesian epistemology can be performed by appreciating the heritage of the past which comes in various forms and styles, which perhaps were no longer practiced in today society. But to grasp the past is not an easy task. In other words, archeological works, and rereading manuscripts, should be promoted to build an epistemological foundation, based upon a new way of reading of the old tradition. What is the difference between reading common history and seeking epistemological foundation through archeology lies in the effort of finding new meanings and reinterpreting not for the sake of narratives or chronological order, but to find a new epistemology, to look for clues where the knowledge did come from in Indonesian context and to what extent the new knowledge can be built based on old and perhaps common materials; this also involves new methods of hermeneutical practices which can lead to new results.

Keep also in mind that later Islamic literature still reflects the old Hindu and Buddha foundation. Take Serat Dewa Ruci for example. ${ }^{37}$ The Serat is a manifestation, and reflection, of the light of Islamic spirit but laid in the foundation of Hindu and Buddhist legacy. The Serat takes hero Bima in the Mababarataas the main protagonist, but the work develops the narrative of search for truth with the cost of the hero's life in a struggle against evil figures: giants, snakes, dangerous caves, ocean and mountains. The story of search for truth can be interpreted as the search of true knowledge, which is later reinterpreted in many shadows puppet plays. ${ }^{38}$ This supports our proposal and endeavor that old material can be recycled in finding new meanings. If Islamic literature in the past presents a new interpretation of the Hindu and Buddhist legacy, modern Indonesian philosophy can do the same task with new methods and perspectives.

${ }^{37}$ Anonym, Punika Sêrat Dewaruci Ingkang Sampun Mawi Wrêdi (Kediri: Tan Gun Swi Kêdhiri, 1928).

${ }^{38}$ Bernard Arps and $\mathrm{Ki}$ Anom Soeroto, Tall tree, nest of the wind: the Javanese shadow-play Dewa Ruci performed by Ki Anom Soeroto: a study in performance philology, 2016. 
Another example of old work which needs a new reading is Babad Tanab Jawa ${ }^{39}$ which also contains the stories of the past based on mythology of a unique Javanese worldview. Certainly, we cannot verify what it contains whether it tells 'reality' or mere 'myth'. But we should read the work in a different way and attitude. That is, we should treat the work as a record of a worldview, and epistemology, describing how Javanese perceived this world. From this work we can learn how history runs based on Javanese wisdom. Indeed, knowledge of reality was produced in this serat, babad and other forms of writing. For example, Serat Diponegoro as discussed and translated by Peter Carey contains many important wisdom, connecting cultures, faiths, politics, economy, and war. ${ }^{40}$ The perception of Javanese about the Dutch hegemony can also be seen in this serat. Thus, through serat we see the past more clearly.

After explaining the possibility and presenting the outline of rereading the legacy of the past, we should realize that modern Indonesian writings offer a richer material with which we can offer different perspectives in reclaiming an epistemology born in Indonesia. Various philosophical and epistemological foundations can lead us to a further criticism and appreciation from which new knowledge can be cultivated in new Indonesian contexts. Certainly, modern Indonesian period covers the first foundation of building Indonesia itself as promoted by the leaders who dreamed of the independence of Indonesia: from Soekarno, Hatta, Tan Malaka, Tjokroaminoto and other leaders. What is clear is that they combined Western philosophy and search of national identity, leading to the foundation of building the nation. Furthermore, modern Indonesian epistemology which was built from the awareness for the independence gave birth to at least two later kinds of thinking: a systematic writing,

${ }^{39}$ W. L. Olthof, ed., Babad Tanah Jawi, Mulai Dari Nabi Adam Sampai Tabun 1647, trans. HR Sumarsono (Yogyakarta: Narasi, 2014).

40 Dipanegara, Babad Dipanagara: An Account of the Outbreak of the Java War, 1825-30: The Surakarta Court Version of the Babad Dipanagara with Translations into English and Indonesian-Malay, trans. P. B. R Carey (Kuala Lumpur: Printed for the Council of the M.B.R.A.S. by Art Printing Works, 1981). 
such as that of Sudjatmoko, ${ }^{41}$ an accessible reading material and non-systematic works, such as the works of those who look for enlightenment through spiritual meditation. Muhammad Subuh, for example, founded Subud movement embraced by people from more than hundred countries in the world. Subuh's works, teachings, and meditation practices are worth learning. ${ }^{42}$ Other books, such as Kitab Sasangka Jati, are also waiting for us to reread with a new spirit. ${ }^{43}$

\section{Conclusion}

Having presented a sketch and outline of possibilities of reclaiming Indonesian philosophy by suggesting to reread and reinterpret the works penned by Indonesian writers, we should be more confident with our own heritage and legacyof intellectual tradition. From the works which do not explicitly declare themselves as 'philosophy' or 'systematic thinking,' we should be able to unearth a system of 'philosophical reflection' in them. This project is a long run, which demands our commitment and patriotism. The realization of the project in unearthing and reclaiming Indonesian philosophy depends on our attitude and spirit whether our faith in our own tradition and culture are firm. In reality, inferiority complex often becomes a main obstacle with the belief that Indonesian literary works and heritage do not produce any system of thinking much less philosophy. Indeed, Indonesian tradition of writing and philosophizing the world, God, and human being cannot be compared to Greece, Latin, Arab, or modern European tradition. Indonesia offers its own way of 'philosophy' in perceiving this reality. Given this, our effort should not cease. Whether Indonesia does have philosophers who produce

${ }^{41}$ Sudjatmoko, Dimensi Manusia dalam Pembangunan: Pilihan Karangan (Jakarta: LP3ES, 1984).

${ }^{42}$ Muhammad Subuh Sumohadiwidjojo, Susila Budbi Dharma Subud: A Poem Received and Written down in High Javanese with a Commentary in Indonesian (Rickmansw orth: Subud, 2001).

${ }^{43} \mathrm{R}$. Soenarto Mertowardojo, Sasangka jati: ngewrat klempakan dhawuh wejanganipun Sang Guru Sajati (Suksma Sajati) (Jakarta: Paguyuban Ngesti Tunggal, 1986). 
philosophical works does not depends on the availability of selfproclaiming philosophers or philosophical works but on the readers who can appreciate and criticize the works of Indonesian writers. In fact, from the periods of Hindu-Buddha, Islam, and Western colonialism, Indonesians, like other people living in other parts of the world, never stop thinking of themselves, their society, environment, faith, and this universe. Our task is to reclaim what are not appreciated well yet and to reread them.

\section{Bibliography}

Ali, Kecia. Imam Shafii: Scholar and Saint. Oxford, England: Oneworld, 2011.

Ansor, Muhammad. "Being Woman in the Land of Shari'a: Politics of the Female Body, Piety, and Resistance in Langsa, Aceh." Al-Jami'ab: Journal of Islamic Studies 52, no. 1 (June 2014): 5983.

Arps, Bernard, and Ki Anom Soeroto. Tall tree, nest of the wind: the Javanese shadow-play Dewa Ruci performed by Ki Anom Soeroto: a study in performance philology, 2016.

Audi, Robert. The Cambridge Dictionary of Philosophy. Cambridge; New York: Cambridge University Press, 1999.

Brandes, Jan Laurens Andries., ed. Pararaton, Ken Arok, of Het Boek Der Koningen van Tumapel En van Majapabit Uitgegeven En Toegelicht Door Dr J. Brandes. Javan. and Dutch. *. 314. 1896, 1896.

Calder, Norman. Studies in Early Muslim Jurisprudence. Oxford: Clarendon Press, 1993.

Campanini, Massimo. "Al-Ghazzali." In History of Philosophy, edited by Seyyed Hossein Nasr and Oliver Leaman, 1:258-274. London: Routledge, 1996.

Commins, Saxe, and Robert N Linscott, eds. Man and Spirit. The Speculative Philosophers. New York: Random House, 1947.

- eds. Man and the State: The Political Philosophers. New York: Random House, 1947.

- eds. Man and the Universe: The Philosophers of Science. New York: Random House, 1947.

Dipanegara. Babad Dipanagara: An Account of the Outbreak of the Java 
War, 1825-30: The Surakarta Court Version of the Babad Dipanagara with Translations into English and Indonesian-Malay. Translated by P. B. R Carey. Kuala Lumpur: Printed for the Council of the M.B.R.A.S. by Art Printing Works, 1981.

Feith, Herbert, Lance Castles, Asia Society, and Asian Literature

Program. Indonesian Political Thinking, 1945-1965,. Ithaca N.Y.:

Cornell University Press, 1970.

Geertz, Clifford. The Religion of Java. Glencoe, Ill.: The Free Press, 1960.

. Abangan, santri, prijayi: dalam masyarakat Jawa. Edited by Bur Rasuanto. Translated by Aswab Mahasin. Jakarta: Pustaka Jaya, 1983.

- Islam Observed: Religions Development Marocco and Indonesia. New Haven [etc.]: Yale University Press, 1968.

- The Interpretation of Cultures: Selected Essays. New York: Basic Books, 1973.

al-Gazaīi, Abū Hāamid Muhammad bin Muhammad. Freedom and Fulfillment: An Annotated Translation of al-Gazäli's al-Munqidh min al-Daläl and Other Relevant Works of al-Gazäli. Translated by Richard Joseph McCarthy. Boston: Twayne Publishers, 1980.

. Deliverance from Error (Al-Munqidh min Al-Daläl). Translated by Richard J. Mccarthy. Beirut: American University of Beirut, 1980.

. Revival of Religion's Sciences/Ibyä' 'Ulüm al-din. Edited by Muhammad Mahdī Sharīf. Beirut: Dār al-Kutub al-'Ilmiyyah, 2011.

Haryono, Timbul. "Neighbouring Temples." edited by Veronique Degroot. Yogyakarta: Tamanwisata candi Borobudur, Prambanan \& Ratu Boko, 2013.

Howell, Julia Day. "Modernity and Islamic Spirituality in Indonesia's New Sufi Networks." In Sufism and The "modern" in Islam, edited by Martin van Bruinessen and Julia Day Howell, 217-240. London, New York; New York: I.B. Tauris; In the U.S.A. and Canada distributed by St. Martin's Press, 2007.

Ishii, Kazuko. "Borobudur, the Tattvasamgraha and the Sang Hyang Kamahayanikan." In The Art and Culture of South-East Asia, edited by Lokesh Chandra, 151-164. New Delhi: International Academy of Indian Culture and Aditya Prakashan, 1991. 
Jabali, Fuad, and Jamhari. The Modernization of Islam in Indonesia: An Impact Study on the Cooperation between the LAIN and McGill University. Jakarta and Montreal: Indonesia Canada Islamic Higher Education Project, 2003.

Kartini. Aku mau ...: feminisme dan nasionalisme: surat-surat Kartini kepada Stella Zeehandelaar 1899-1903. Translated by Vissia Ita. Yulianto. Jakarta; Yogyakarta: Buku Kompas ; [Program Pasca Sarjana Ilmu Religi dan Budaya (IRB), Universitas Sanata Dharma Press] IRB Press, 2004.

- Letters from Kartini: An Indonesian Feminist, 1900-1904. Clayton, Vic.; Melbourne, Vic.: Monash Asia Institute, Monash University; Hyland House, 1992.

- Surat-surat Kartini: renungan tentang dan untuk bangsanya. Translated by Sulastin, Sutrisno. Jakarta: Djambatan, 1979.

Koninklijk Instituut voor Taal-, Land- en Volkenkunde (LEYDEN), and Kamahāyānikan. Sang Hyang Kamabâyanikan. (Sang Hyang Kamahâyanan Mantranaya.) [Treatises on the Mystical and Magical Teachings of the Mantra-Yana School of Northerm Buddhism, in a Series of Sanskrit Stanzas with Javanese Exposition.] Oud-Javaansche Tekst Met Inleid. s' Gravenhage, 1910.

Makin, Al. "Benedict XVI and Islam: Indonesian Public Reactions to the Regensburg Address." Islam and Christian-Muslim Relations 20, no. 4 (2009): 409-421.

- Challenging Islamic Orbtodoxy: The Accoounts of Lia Eden and Other Prophets in Indonesia. Dordrecht, Holland; Cinnaminson [N.J.], U.S.A.: Springer, 2016.

-. LAIN and McGIll Cooperation, 10 Years: Past and Future. Yogyakarta: Local Project Implementing Unit, 2003.

-. Keragaman Dan Perbedaan, Budaya Dan Agama Dalam Lintas Sejarah Manusia. Yogyakarta: Suka Press, 2016.

—. "Revisiting Indonesian Public Reactions against Danish Cartoons Depicting Prophet Muhammad." Indonesian Journal of Islam and Muslim Societies 5, no. 2 (2015): 195-229.

Malaka, Tan. Madilog, Materialisme Dialektika Logika. Jakarta: LPPM Tan Malaka, 2008.

- Naar de Republiek Indonesia, 2013.

Mertowardojo, R. Soenarto. Sasangka jati: ngewrat klempakan dhawuh wejanganipun Sang Guru Sajati (Suksma Sajati). Jakarta: Paguyuban Ngesti Tunggal, 1986. 
Miksic, John N. Borobudur: Golden Tales of the Buddhas. Hongkong: Periplus, 1991.

Miksic, John N, and Slamet Pinardi. Kraton Ratu Boko: a Javanese site of enigmatic beauty. Yogyakarta: Tamanwisata candi Borobudur, Prambanan \& Ratu Boko, 2015.

Muljana, Slamet. Tafsir Sejarah Negara Kretagama. Yogyakarta: LKis, 2006.

Notosusanto, Nugroho. Sejarah nasional Indonesia untuk SMP. Jakarta: Departemen Pendidikan dan Kebudayaan: Balai Pustaka, 1985.

- Tentara Peta pada jaman pendudukan jepang di Indonesia. Jakarata: Gramedia, 1979.

- Terapainya konsensus nasional, 1966-1969. Jakarta: Balai Pustaka, 1985.

Notosusanto, Nugroho, Yusmar Basri, Indonesia, and Departemen Pendidikan dan Kebudayaan. Sejarah nasional Indonesia: untuk $S M A$. Jakarta: Departemen Pendidikan dan Kebudayaan, 1981.

Olthof, W. L., ed. Babad Tanah Jawi, Mulai Dari Nabi Adam Sampai Tabun 1647. Translated by HR Sumarsono. Yogyakarta: Narasi, 2014.

Panitya Penyusun Penterjemahan, and Sanghyang Kamahayanikan. Kitab Suci Sanghyang Kamahayanikan: Naskab-TerjemahanPenjelasannya. Tahun: Proyek Pengadaan Kitab Suci Buddha, 1980.

Plato. The republic. Edited by G. R. F Ferrari. Translated by Tom Griffith. Cambridge; New York: Cambridge University Press, 2000.

Procter, Paul, ed. Cambridge International Dictionary of English. Cambridge; New York: Cambridge University Press, 1995.

Roosa, John. Pretext for Mass Murder the September 30th Movement and Subarto's Coup D'etat in Indonesia. Madison, Wis.: University of Wisconsin Press, 2006.

Russell, Bertrand. History of Western Philosopby and Its Connection with Political and Social Circumstances from the Earliest Times to the Present Day. London: Routledge, 1999.

Sangidu. "Allah Maujud Terlalu Baqi Karya Syeikh Hamzah Fansuri: Analisis Semiotik." Diksi 11, no. 1 (2004): 1-19.

. "Ikan Tunggal Bernama Fadhil Karya Syeikh Hamzah

Fansuri: Analisis Semiotik." Humaniora 15, no. 2 (2003): 191- 
199.

"'Sidang Fakir Empunya Kata' Karya Syaikh Hamzah Fansuri Kajian Filologis Dan Analisis Semiotik." Humaniora 14, no. 3 (2002): 306-317.

Simbolon, Parakitri Tahi. Menjadi Indonesia. Jakarta: Kompas, 1995.

Soekarno. Dibawah Bendera Revolusi. Djakarta: Panitya Penerbit Dibawah Bendera Revolusi, 1963.

-. "Nasionalisme, Islamisme, dan Marxisme." In Dibawah Bendera Revolusi., 1-22. Jakarta: Yayasan Bung Karno, 2005.

Sudjatmoko. Dimensi Manusia dalam Pembangunan: Piliban Karangan. Jakarta: LP3ES, 1984.

Sugriwa, I. Gusti Bagus. Kitab sutï "Sanghyang Kamahayanikan." Denpasar: Pustaka Balimas, 1956.

Sumohadiwidjojo, Muhammad Subuh. Susila Budhi Dharma Subud: A Poem Received and Written down in High Javanese with a Commentary in Indonesian. Rickmansworth: Subud, 2001.

Syarifuddin. "Memperdebat Wujudiyah Syeikh Hamzah Fansuri (Kajian Hermeneutik Atas Karya Sastra Hamzah Fansuri)." Religia 13, no. 2 (2010): 139-156.

Tjokroaminoto, Umar Said,. Islam dan Sosialisme (tertulis di Mataram dalam bulan November 1924). Djakarta: Bulan-Bintang, 1954.

Bhagavad-Gita; or the Secred Lay: A Colloquy between Krisna and Arjuna on Divine Matter, an Episode from the Mababharata; a New Edition of the Sanskrit Text with a Vocabulary, by J. Cockburn Thomson, and Translated by the Same, with Copious Notes and I. Hertford: Austin, 1855.

"Permasalahan Implementasi Perda Syariah Dalam Otonomi Daerah: View Article." Journal al-Manahij7, no. 2 (2013).

Punika Sêrat Dewaruci Ingkang Sampun Mawi Wrêdi. Kediri: Tan Gun Swi Kêdhiri, 1928.

Tan Malaka's Naar de Republiek Indonesia: A Translation and Commentary : Geoffrey C. Gunn. Nagasaki, Japan: Hakkojo, 1996. 